6

\title{
IMPROVEMENT IN NITRIFICATION THROUGH THE USE OF NATURAL ZEOLITE: INFLUENCE OF THE BIOMASS CONCENTRATION AND INOCULUM SOURCE
}

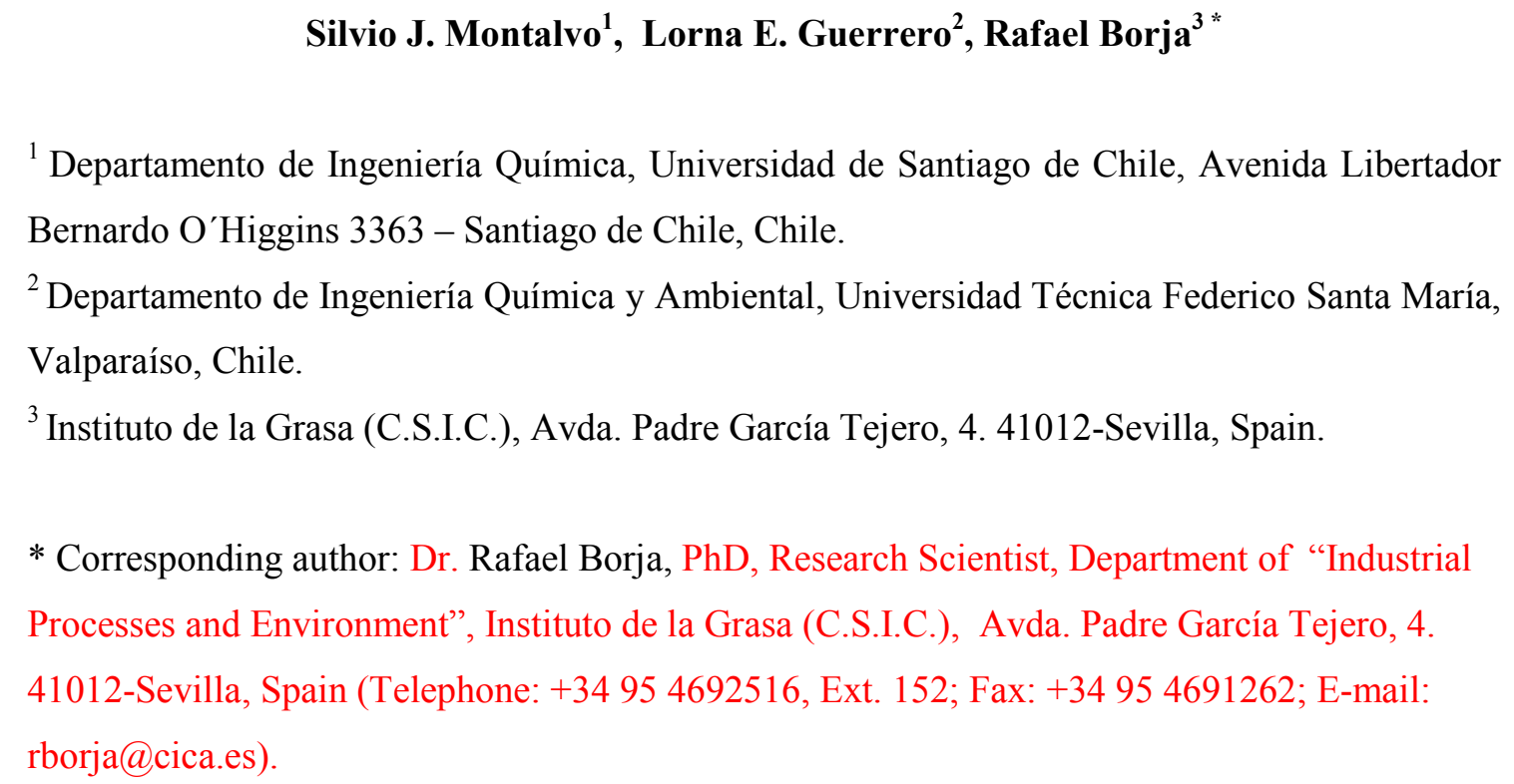

\section{ABSTRACT}

A batch nitrification process was studied using synthetic wastewater as substrate and Chilean natural zeolite as biomass carrier at ambient temperatures $\left(20^{\circ} \mathrm{C}\right)$. Three groups of experiments were carried out: a first experimental set (I) with and without added zeolite using initial biomass concentrations of 1,000 and 2,000 mg VSS/L; a second set of experiments (II) with added zeolite and at the same initial biomass concentrations. In these two experimental sets, biomass from an activated sludge process located in an urban wastewater treatment plant (WWTP) at La Farfana, Santiago de Chile, was used as inoculum (1). Finally, a third set of experiments (III) was carried out with zeolite at an initial biomass concentration of 1,000 mg VSS/L using an inoculum derived from an activated sludge process treating wastewater from a paper mill (inoculum 2). Nitrifying biomass concentration values in the range of 13,000-18,800 $\mathrm{mg}$ VSS/L were achieved when initial biomass concentrations varied between 1000-2000 mg VSS/L. Inoculum (1) generated higher biomass concentrations than inoculum (2). Ammonium $\mathrm{N}$ removals higher than $70 \%$ were obtained in experimental sets II and III when zeolite was used. For both initial biomass concentrations tested, an exponential biomass growth was observed up to the second day of operation, and a slight decrease was evident afterwards, achieving stationary values after 10-12 days of operation. The third experimental set (III) revealed that the highest $\mathrm{N}$ consumption took place between days 11 and 16 of digestion. 
Key words: $\quad$ batch mode, inoculum type, nitrifying biomass carrier, zeolite.

\section{INTRODUCTION}

Because of its increased use as an artifical addition, one of the most problematic and wellknown pollutants is nitrogen in its diverse forms, a phenomenon already considered to be a new environmental global change of unforeseeable consequences (Tortosa et al., 2011). The main sources of nitrogen are chemical fertilizers (nitrate, ammonia and urea), agricultural and animal wastes (nitrite and ammonia) and industrial liquid effluents (nitrite, nitrate and ammonia) (Nemerow, 1991). In the literature, different negative effects have been described thoroughly, among which eutrophication (fertilization in excess) should be highlighted, as it causes the excessive growth of algae and aquatic plants (Guo et al., 2010; Zaman, 2010). In 2008, it affected $54 \%$ of Asian lakes, $53 \%$ of European lakes, $48 \%$ of North American lakes, $41 \%$ of South American and 28\% of African lakes.

In addition, the direct effects of nitrogen compounds on the aquatic systems, indirect effects resulting from the nitrogen gases that are generated from the liquid wastes, such as $\mathrm{NO}_{\mathrm{x}}$ substances, also contribute either to the greenhouse effect or to acid rain (Wang et al., 2008). There are two main methods for removing nitrogen from wastewaters: physico-chemical and biological processes (Guo et al., 2008). The physico-chemical processes such as air and stream stripping are sometimes used for the control of nitrogen in strong nitrogen wastewaters. However, from environmental and economic viewpoints, it would be more interesting to use biological nitrogen removal for treating high ammonium strength wastewaters. Its removal process has been widely adopted in preference to the physico-chemical processes because of its higher effectiveness and relatively low cost, especially in the field of urban wastewater treatment (Guo et al., 2008). Among the biological methods, the nitrification-denitrification system is the most widely used alternative (Leu et al., 2010; Liu et al., 2007; Pagga et al., 2006).

The efficiency of the biological processes, such as nitrification-denitrification, can be improved by increasing the microorganism retention time, which is usually independent from the wastewater retention time. In most cases this is achieved by the immobilization of microorganisms (Yan and $\mathrm{Hu}, 2009$ ). Biofilm reactors are especially useful when slow growing organisms like nitrifiers have to be kept in a wastewater treatment process. Due to the efficient biomass retention, long sludge ages and more compact reactors can easily be achieved (Hooshyari et al., 2009).

However, a restrictive factor for the suitability of this technological alternative (nitrification - denitrification) is that the microorganism support medium or bacterial carrier have to fulfill the following main characteristics: its surface should favour the adherence and colonization of 
the microorganisms, it should be physically and chemically resistant and relatively inert (Liu et al., 2007; Rostron et al., 2001). Several previous research works have demonstrated that natural zeolites meet these characteristics (Fernández et al., 2007; Nikolaeva et al., 2009). However, the specific behaviour of the zeolites in each process is different depending on the type of microorganisms involved in each case. As a consequence, the need to assess the nitrification process using natural zeolite as microorganism carrier for this process (Liu et al., 2007; Rostron et al., 2001) has emerged.

Natural zeolites are crystalline, hydrated aluminosilicates of alkali and alkaline earth cations, consisting of three-dimensional frameworks of $\mathrm{SiO}_{4}{ }^{4-}$ and $\mathrm{AlO}_{4}{ }^{5-}$ tetrahedra linked through shared oxygen atoms (Tashauoei et al., 2010). They are porous materials characterized by their ability to 1) lose and gain water reversibly, 2) adsorb molecules of appropriate crosssectional diameter (adsorption property or acting as molecule sieves) and 3) exchange their constituent cations without a major change in their structure (ion-exchange property). The exploitation of these properties underlies the use of zeolites in a wide range of industrial, agricultural and contamination prevention applications (Milán et al., 2001a, b and c; Tashauoei et al., 2010). The structure and physical properties of natural zeolite [channel and pore cavities, minimum diameter of pores in the range of 3 to 10 Angstroms, average surface area of 24.9 $\mathrm{m}^{2} / \mathrm{g}$, low bulk density, high exchange (CEC) and adsorption capacities] make it ideal for use in biological purification wastewater processes (Carretero and Pozo, 2009). Consequently, the use of natural zeolite in different wastewater biological treatment processes has increased significantly over the past few years.

Therefore, taking previous works into account, the aim of this paper was to make a comparative study of the nitrification process with and without natural zeolites as microorganism immobilization support or carrier while simultaneously assessing the influence of the initial biomass concentration and the inoculum source. All this research was carried out in

100 the laboratories of the Department of Chemical Engineering of the University of Santiago de

101 Chile and of the Department of Chemical and Environmental Engineering of the "Federico

102 Santa María" Technical University of Valparaiso (Chile). These experiments were made within 103 the period November 2010-July 2011.

MATERIALS AND METHODS

Experimental design

109 Three different sets or groups of experiments were carried out:

110 I) A first set of experiments comparing a batch nitrification process with and without 111 added zeolite, using two different initial biomass concentrations $(1,000$ and 2,000 
mg VSS/L). Biomass from an activated sludge process belonging to an urban wastewater treatment plant (UWTP) called La Farfana located in Santiago de Chile (Chile), was used as inoculum in the reactors. The evolution of biomass concentration over time was assessed.

A second set of batch nitrification experiments with added zeolite and initial

III) A third set of batch nitrification experiments with added zeolite and an initial biomass concentrations of 1,000 and $2,000 \mathrm{mg} \mathrm{VSS} / \mathrm{L}$. The same inoculum was

\section{Zeolite used} used. The bacterial growth, the decrease in ammonium concentration and formation of nitrate over time were evaluated in this case.

Chilean natural zeolite supplied by "Minera Formas", Chile (named "ZeoClean R") was used in the experiments. Table 1 shows the main chemical composition of this zeolite. The phase composition $(\% \mathrm{w} / \mathrm{w})$ of the zeolite was: $35 \%$ Clinoptilolite, $15 \%$ Mordenite, $30 \%$

\section{Chemical analyses}

133 Chemical oxygen demand (COD), solids and total phosphorus analyses were carried out 134 according to Standard Methods for the Examination of Waters and Wastewaters (APHA, 1995).

135 Nitrate, ammonium nitrogen, $\mathrm{pH}$ and dissolved oxygen (DO) were determined by selective 136 electrodes.

\section{Experimental procedure}

\section{Set of experiments I and II}

140 Experimental sets I and II were carried out at ambient temperature (an average of $20^{\circ} \mathrm{C}$ ) 141 in glass reactors of $200 \mathrm{~mL}$ working volume, in which synthetic wastewater was added. Table 2 142 shows the composition and main characteristics of the synthetic wastewater used as substrate in 143 these experiments. Aerobic biomass from a full-scale activated sludge process located in the 144 Urban Wastewater Treatment Plant (UWTP) at La Farfana was used as inoculum in both 145 groups of experiments. The characteristics of this biomass were: total suspended solids (TSS), $1468,950 \mathrm{mg} / \mathrm{L}$; volatile suspended solids (VSS), 7,300 mg/L; $\mathrm{pH}, 7.2$; and sludge volume index 147 (SVI), $150 \mathrm{~mL} / \mathrm{g}$. Air was supplied to these reactors with a flow rate of $20 \mathrm{~L} / \mathrm{min}$. The air was 148 injected through the bottom of the reactor using a porous ceramic diffuser. In addition, each 
reactor had a detachable grille located in the upper part to avoid microorganisms being lost in

150 the reactor effluents as a consequence of the breaking of the air bubbles in the interface gas-

151 liquid.

152 At the beginning of the experiments and every 2 days thereafter, two reactors were selected and sampled with the aim of obtaining duplicate results. Once these two reactors were finished with, $30 \mathrm{~mL}$ of synthetic wastewater was added to the rest of reactors to balance the evaporation losses.

During the first set of experiments (I) the behaviour of the nitrification process with and without added zeolite was evaluated in batch mode and in parallel by using initial biomass concentrations of 1,000 and 2,000 $\mathrm{mg} \mathrm{VSS} / \mathrm{L}$. A total of 32 reactors was used: 16 with zeolite and 16 without zeolite. During this first set of experiments, the variation of biomass concentration over time was measured.

During the second set of experiments (II) the batch nitrification process was evaluated using only reactors with added zeolite and two different initial biomass concentrations (1,000 and $2,000 \mathrm{mg} \mathrm{VSS} / \mathrm{L}$ ). 32 reactors were used for each of these concentrations. For the reactors with an initial biomass concentration of $1,000 \mathrm{mg} \mathrm{VSS} / \mathrm{L}, 6 \mathrm{~mL}$ of inoculum were added, while for those with 2,000 $\mathrm{mg} \mathrm{VSS} / \mathrm{L}, 12 \mathrm{~mL}$ of inoculum were added, completing the remaining volume with synthetic wastewater in both cases. The variation of biomass concentration, ammonium removal and nitrate formation over time were assessed during this second set of experiments.

In all cases the amount of zeolite added (with the characteristics shown in Table 1) corresponded to a ratio of $40 \mathrm{mg} \mathrm{VSS} / \mathrm{g}$ zeolite. The duration of the set of experiments I and II ranged from 8 to 15 days.

\section{Set of experiments III}

173 This set of experiments was carried out in triplicate at ambient or room temperature 174 (average of $20^{\circ} \mathrm{C}$ ) using reactors of $350 \mathrm{~mL}$ working volume with the same synthetic substrate as described in Table 2.

176 This group of batch nitrification experiments was carried out with added zeolite and an initial biomass concentration of $1,000 \mathrm{mg} \mathrm{VSS} / \mathrm{L}$. An inoculum from an activated sludge process treating wastewater from a paper manufacture factory was used in this case. The characteristics of this biomass were: TSS, 7,500 mg/L; VSS, 6,400 mg/L; pH, 7.1; and SVI, 300 $\mathrm{mL} / \mathrm{g}$. The bacterial growth, $\mathrm{pH}$ variation, decrease in ammonium concentration and formation of nitrate over time were assessed in this third set of experiments. The duration of the three experiments carried out in parallel was 16 days. 


\section{Set of experiments $I$}

188 Experiments with an initial biomass concentration of 1,000 $\mathrm{mg}$ VSS/L

189 Figures 1 and 2 show the variation of the biomass concentration (mg VSS/L) over time for 190 the experiments with and without added zeolite, respectively. As can be seen in the first case, 191 there was an increase in the biomass concentration until a maximum value of $18,500 \mathrm{mg} \mathrm{VSS} / \mathrm{L}$ 192 after two days of digestion time was achieved, which afterwards decreased slightly to a stable 193 value of $15,300 \mathrm{mg} \mathrm{VSS} / \mathrm{L}$ on the $15^{\text {th }}$ day of operation. By contrast, in the reactors without 194 zeolite, there was a continuous decrease in the biomass concentration over time achieving a 195 minimum concentration of $600 \mathrm{mg} / \mathrm{L}$ after 9 days of operation. This behavior can be explained 196 not only by the fact that zeolite acted as a microorganism carrier but also because the reactors 197 without bacterial support are more prone to ammonia volatility (the main substrate of the process) and to the destabilization caused by the high flow of air used in the experiments.

Similar initial biomass concentrations $(1,700 \mathrm{mg}$ VSS/L) were used in experiments of partial nitrification carried out in sequencing batch reactors (SBR) under aeration rates in the range of 0.1-1.6 L/min (Wu et al., 2009).

Experiments with an initial biomass concentration of 2,000 $\mathrm{mg}$ VSS/L

Figures 3 and 4 illustrate the evolution of the biomass concentration (mg VSS/L) over time for the experiments with and without added zeolite respectively, when the initial biomass concentration was 2,000 mg VSS/L. As can be observed when zeolite was used as a biomass carrier, there was an increase in the biomass during the first two days of operation achieving a maximum value of $18,900 \mathrm{mg} \mathrm{VSS} / \mathrm{L}$, while decreasing slightly and stabilizing after the $4^{\text {th }}$ day of operation, at a value of $15,000 \mathrm{mg} \mathrm{VSS} / \mathrm{L}$. On the other hand, for the reactors without zeolite a decrease in the VSS concentration from 2,000 to $650 \mathrm{mg} / \mathrm{L}$ was detected after 8 days of operation time.

212 The same biomass evolution as that observed in the present work with added zeolite was

213 also detected in an activated sludge system with fireclay (excess sludge from ceramic and tile

214 manufacturing plants) as the biomass carrier operating in batch mode with an initial biomass

215 concentration of $2,400 \mathrm{mg} / \mathrm{L}$ (Tilaki, 2011). When the amount of fireclay was increased (to values higher than $2,250 \mathrm{mg} / \mathrm{L}$ ) the total biomass concentration was also increased.

\section{Set of experiments II}

219 This set of experiments was carried out with initial biomass concentrations of 1,000 and 2,000 $\mathrm{mg} \mathrm{VSS} / \mathrm{L}$, the initial ammonium concentration in the synthetic wastewater and inoculum at 148 and $73 \mathrm{ppm}$, respectively. The inoculum was derived from an activated sludge system installed in the Urban WWTP at La Farfana (Santiago de Chile, Chile). 
224 Experiments with an initial biomass concentration of 1,000 $\mathrm{mg} \mathrm{VSS} / \mathrm{L}$

225 Figure 5 shows the variation of the biomass concentration over time. As can be seen, an 226 exponential growth was observed during the first two days of operation achieving a maximum 227 value of $18,550 \mathrm{mg} / \mathrm{L}$. From day 4 onward, the microorganism concentration remained virtually 228 constant with a value of about $15,000 \mathrm{mg} \mathrm{VSS} / \mathrm{L}$. Therefore, the addition of $30 \mathrm{~mL}$ of synthetic 229 wastewater to the reactors every two days to compensate for the evaporation losses meant that 230 the biomass concentration remained constant over time.

231 On the other hand, no lag phase was observed because the inoculum used was derived from 232 a previous aerobic process and, therefore, an adaptation or acclimation period was not 233 necessary. The exponential phase or step was clearly evident during the first two days of 234 operation, a time lapse for which there was no nutrient restriction reaching a maximum VSS 235 concentration of $18,550 \mathrm{mg} / \mathrm{L}$. From day 2 onward, a stationary phase was started due to the 236 depletion of some of the nutrients, although the addition of the above-mentioned volume of 237 fresh wastewater every two days determined that the dead stage of the microorganisms cannot 238 be clearly observed.

239 Finally, Figure 6 shows the variation of the ammonium concentration over time. As can be 240 seen, a gradual decrease in the ammonium concentration over time was observed up to a 241 constant value after the $12^{\text {th }}$ day of digestion. Simultaneously a gradual increase in nitrate 242 concentration was observed over time (Figure 7), the nitrate being the final product of the 243 nitrification process. It is worth noting that the ammonium that did not transform into nitrate can 244 be found as nitrite although this is unlikely as a consequence of the high DO concentrations $245(2.8-4.9 \mathrm{mg} / \mathrm{L})$ measured in the reactors. In addition, part of the initial ammonium could have 246 been evaporated due to the high aeration levels and another part could have been adhered to the zeolite or added to the microorganism cells present in the medium.

\section{Experiments with an initial biomass concentration of 2,000 $\mathrm{mg} \mathrm{VSS} / \mathrm{L}$}

250

The variation of the biomass concentration over time is illustrated in Figure 8 and showed similar behaviour to that observed when the initial biomass concentration was $1,000 \mathrm{mg} \mathrm{VSS} / \mathrm{L}$. An exponential growth was observed up to the $2^{\text {nd }}$ day of digestion, in which a maximum concentration of $18,800 \mathrm{mg}$ VSS/L was achieved. From the $4^{\text {th }}$ day onward, the increase in the VSS concentration tended to be constant despite the previously mentioned synthetic wastewater being added every 2 days.

In addition, there was no lag phase because the inoculum used came from an urban WWTP and no acclimation stage was necessary. The stationary stage occurred after the $4^{\text {th }}$ day of operation and was reached despite the reactors being fed with $30 \mathrm{~mL}$ of synthetic wastewater every 2 days. As a consequence of this batch feed system, the microorganism dead phase was 
not observed. Similar initial biomass concentrations (1,750 mg VSS/L) also behaved well in nitrifying SBR systems operating in continuous mode at an HRT of 1 day treating reject water

262 (Pérez et al., 2007).

263 A gradual decrease in the ammonium concentration over time was observed until a relatively constant value after the $10^{\text {th }}$ of digestion was reached (Figure 9). The maximum reduction of ammonium in the liquid medium was approximately $70 \%$. Figure 10 confirms that nitrate was obtained as a final product of the process. Effective nitrification was also reported in SBR systems treating reject water (supernatant of an anaerobic sludge digestion) with initial biomass concentrations of $3,500 \mathrm{mg} / \mathrm{L}$ and initial ammonium concentrations of up to 1,200 mg/L (Galí et al., 2006).

Therefore, it can be concluded that the inoculum from an Urban WWTP was very effective in the batch nitrification process described in the present work. Similar inoculum sources were shown to be interesting and efficient in other nitrification processes reported in the literature using batch reactors treating synthetic and sludge liquors mixed with wastewater from diesel production (Canto et al., 2008; Malá and Maly, 2010).

\section{Set of experiments III}

For this group of experiments, the assays were carried out in triplicate with the aim of obtaining higher representative results. This group of batch nitrification experiments was carried out using zeolite and an initial biomass concentration of 1,000 mg VSS/L. An inoculum from an activated sludge process treating wastewater from a paper factory was used in this case.

Given that the biomass concentration is directly related to the ammonium concentration, the evolution of the biomass over time was assessed during the three assays made within this experimental set. Table 3 shows the variation of the average VSS concentration for these three assays over time. As can be seen, a considerable increase in the biomass concentration with operation time was observed, achieving maximum VSS concentrations higher than 13,000 mg/L on the $12^{\text {th }}$ day of operation. It is worth considering this when a full-scale nitrification process is started. Once the maximum biomass concentration value was reached, a slight decrease was observed. This may be due to the presence of insufficient amounts of substrate available for the microorganisms at these high biomass concentration values.

A rapid growth of nitrifying bacteria also took place after 12 days of operation during the nitrification process of poultry slaughterhouse wastewater in a lab-scale aerobic fixed film reactor (Del Pozo et al., 2004). However, lower biomass concentrations (5.45 g VSS/L) were achieved in an aerobic fixed-bed bioreactor operating in continuous mode at an HRT of $3.5 \mathrm{~h}$ using an acclimated municipal biosludge and 4-nitroaniline as carbon sources (Saupe, 1999).

The $\mathrm{pH}$ has a tendency to decrease due to the fact that the conversion of $\mathrm{NH}_{4}{ }^{+}$to $\mathrm{NO}_{3}{ }^{-}$ involves the transformation of an alkaline ion into an acid ion as follows: 


$$
\mathrm{NH}_{4}^{+}+2 \mathrm{O}_{2} \rightarrow \mathrm{NO}_{3}^{-}+\mathrm{H}_{2} \mathrm{O}+2 \mathrm{H}^{+}
$$

Table 3 also shows the variation of the average $\mathrm{pH}$ with the digestion time. As can be observed, the lower $\mathrm{pH}$ values were found between days 10 and 12 , which is when the maximum amount of biomass was produced.

Table 4 summarizes the evolution of ammonium and nitrate concentrations (average values of the three experimental runs and expressed in molar concentration) with operation time. It can be observed a slight increase in the $\mathrm{NH}_{4}{ }^{+}$concentration with time throughout the 16 days of the assay. By contrast, the $\mathrm{NO}_{3}{ }^{-}$concentration increased slightly during the first 8 days, showing a considerable increase between the $10^{\text {th }}$ and $12^{\text {th }}$ day, for which a maximum concentration of 0.02 (molar) was achieved.

A previous nitrification study carried out with a special biomass carrier made of a mixture of zeolite and pellets of sodium alginate (1-2 mm diameter), revealed that the physical airstripping effect was stronger than both chemical ion exchange and biological nitrification effects occurring in the system for initial ammonium concentration levels of 10-20 mg N/L (Yan, 1997).

When comparing the biomass production with this inoculum and with the previously studied incoculum derived from an activated sludge process located in an urban WWTP (set of experiments I and II) by using the same initial biomass concentrations (1,000 $\mathrm{mg} \mathrm{VSS} / \mathrm{L})$, it can

315 be concluded that lower maximum biomass generation $(13,000 \mathrm{mg} \mathrm{VSS} / \mathrm{L})$ was obtained with

316 the sludge derived from the activated sludge process treating wastewater from a paper factory as 317 compared with the first biomass used $(18,800 \mathrm{mg} \mathrm{VSS} / \mathrm{L})$.

318 Nitrogen consumption was calculated from the measurements made during the different time periods taking into account that $30 \mathrm{~mL}$ of synthetic wastewater containing ammonium were added every two days. The nitrogenous chemical species that were considered for this analysis were: ammonia (liquid), ammonia (gas), $\mathrm{NO}_{3}^{-}$, all of them measured with selective electrodes, $\mathrm{N}_{\text {biomass }}$ measured in the biomass adhered to zeolite and $\mathrm{N}_{\text {zeolite }}$ calculated from the ionic exchange capacity of the zeolite and data provided by the zeolite supplier (ZeoClean R).

324 The results obtained in this $\mathrm{N}$ balance were gathered together in three time intervals: from 1 to 6 days (period 1); from 7 to 10 days (period 2); and from 11 to 16 days (period 3) for a better analysis. The average $\mathrm{N}$ consumption of the three experimental runs carried out within the set of experiments III were found to be $14 \%, 23 \%$ and $46 \%$ for the time periods 1, 2 and 3, respectively, amounting the $\mathrm{N}$ losses an average value of $17 \%$.

Therefore, the higher $\mathrm{N}$ consumption took place between days 11 and 16, which coincided with the maximum biomass concentration generated and maximum ammonium removal. As expected, $\mathrm{N}$ consumption is directly related to the amount of biomass generated. Of $100 \%$ of $\mathrm{N}$ added, an average of $46 \%$ was consumed in the time interval between 11-16 days. It was noteworthy that the loss of nitrogen was high (average of 17\%), which was due to the 
experimental conditions used with a high air flow, which determined DO concentration values in the range of 4.7-6.2 ppm contributing to a high level of ammonia stripping.

336 It has also been reported in another batch nitrification process with zeolite (with the dual purpose of ion exchanger and physical carrier for nitrifying bacteria) that nitrite and oxygen concentrations were determined as the major parameters responsible for the formation of gaseous $\mathrm{N}\left(\mathrm{N}_{2}\right.$ and $\left.\mathrm{N}_{2} \mathrm{O}\right)$ and, therefore, for nitrogen losses (Green et al., 2002).

\section{CONCLUSIONS}

It can be concluded from these studies that the use of natural zeolite as a nitrifying microorganisms carrier offers clear advantages over nitrification systems without added zeolite.

345 Despite using a batch feed system rather than a continuous one, high ammonium concentration removals were obtained (higher than $70 \%$ ). The growth of nitrifying biomass achieved high values ranging between 13,000 and 18,800 mg VSS/L starting from inocula with 1,000-2,000 $\mathrm{mg}$ VSS/L. The two inocula assayed were found to be very effective, generating higher biomass concentrations from the sludge derived from an activated sludge process located in an Urban WWTP. An increase in the VSS concentration brought about a decrease in the ammonium concentration and an increase in the nitrate concentration, which is also a consequence of the nitrogenous biomass formation.

\section{ACKNOWLEDGEMENTS}

The authors wish to express their gratitude to FONDECYT project no. 1090414 (Chile) and to the University of Santiago de Chile (Chile) for providing financial support.

\section{REFERENCES}

American Public Health Association (APHA), (1995). Standard Methods for the Examination of Water and Wastewater $19^{\text {th }}$ edn, American Public Health Association / American Water Works Association / Water Environment Federation, Washington DC, USA.

Canto, C.S.A.; Ratusznei, S.M.; Rodrigues, J.A.D.; Zaiat, M.; Foresti, E., (2008). Effect of ammonia load on efficiency of nitrogen renoval in an SBBR with liquid-phase circulation. Braz. J. Chem. Eng., 25 (2), 275-289.

Carretero, M.I.; Pozo, M., (2009). Clay and non-clay minerals in the pharmaceutical industry, Part I. Excipients and medical applications. Appl. Clay Sci., 46, 73-80. 
Del Pozo, R.; Diez, V.; Salazar, G., (2004). Nitrogen and organic matter removal from slaughterhouse wastewater in a lab-scale aerobic fixed-film bioreactor. Environ. Technol., 25 (6), 713-721.

Fernández, N.; Montalvo, S.; Fernández-Polanco, F.; Guerrero, L.; Cortés, I.; Borja, R.; Sánchez, E.; Travieso, L., (2007). Real evidence about zeolite as microorgasnims immobilizer in anaerobic fluidized bed reactors. Process Biochem., 42, 721-728.

Galí, A.; Dosta, J.; Macé, S.; Mata-Alvarez, J., (2006). Start-up of a biological sequencing batch reactor to treat supernatant from anaerobic sludge digester. Environ. Technol., 27 (8), 891899.

Green, M.; Denekamp, N.; Lahav, O.; Tarre, S., (2002). Production of gaseous nitrogen compounds in a novel process for ammonium removal. Water Sci. Technol., 46 (1-2), $215-$ 222.

Guo, X.; Kim, J.H.; Behera, S.K.; Park, H.S., (2008). Influence of dissolved oxygen concentration and aeration time on nitrite accumulation in partial nitrification process. Int. J. Environ. Sci. Technol., 5 (4), 527-534.

Guo, J.; Peng, Y.; Huang, H.; Wang, G.Sh.; Zhang, J., (2010). Short- and long-term effects of temperature on partial nitrification in a sequencing batch reactor treating domestic wastewater. J. Hazard. Mat., 179, 471-479.

Hooshyari, B.; Azimi, A.; Mehrdadi, N., (2009). Kinetic analysis of enhanced biological phosphorus removal in a hybrid integrated fixed film activated sludge process. Int. J. Environ. Sci. Technol., 6 (1), 149-158.

Leu, S.Y.; Libra, J.A.; Stenstrom, M.K., (2010). Monitoring off-gas $\mathrm{O}_{2} / \mathrm{CO}_{2}$ to predict nitrification performance in activated sludge processes. Water Res., 44, 3434-3444.

Liu, Y.Q.; Moy, B.Y.P.; Tay J.H., (2007). COD removal and nitrification of low - strength domestic wastewater in aerobic granular sludge sequencing batch reactors. Enzyme Microb. Technol., 42, 23-28.

Malá, J.; Maly, J., (2010). Wastewater from biodiesel production as a carbon source for denitrification of sludge liquor in SBR. Chem. Biochem. Eng. Q., 24 (2), 211-217.

Milán, Z.; Sánchez, E.; Weiland, P.; Borja, R.; Martín, A.; Ilangovan, K., (2001a). Influence of different natural zeolite concentrations on the anaerobic digestion of piggery waste. Bioresour. Technol., 80, 37-43.

Milán, Z.; Sánchez, E.; Borja, R.; Weiland, P.; Cruz, M., (2001b). Synergistic effects of natural and modified zeolites on the methanogenesis of acetate and methanol. Biotechnol. Lett., $23,559-562$.

Milán, Z.; de las Pozas, C.; Cruz, M.; Borja, R.; Sánchez, E.; Ilangovan, K.; Espinosa, Y.; Luna, B., (2001c). The removal of bacteria by modified natural zeolites. J. Environ. Sci. Health Pt. A 36, 1073-1087. 
Nemerow, N.L., (1991). Industrial and Hazardous Waste Treatment, Ed. Van Nostrand Reinhold, New Cork, USA.

Nikolaeva, S.; Sánchez, E.; Borja, R.; Raposo, F.; Colmenarejo, M.F.; Montalvo, S.; Jiménez-

410 Rodríguez, A.M., (2009). Kinetics of anaerobic degradation of screened dairy manure by 411 upflow fixed bed digesters: Effect of natural zeolite addition. J. Environ. Sci. Health Pt. A, 44, 146-154.

Pagga, U.; Bachner, J.; Strotmann, U., (2006). Inhibition of nitrification in laboratory tests and model wastewater treatment plants. Chemosphere, 65, 1-8.

Perez, R.; Galí, A.; Dosta, J.; Mata-Alvarez, J., (2007). Biological nitrogen renoval (BNR) using sulfides for autotrophic denitrification in a sequencing batch reactor (SBR) to treat reject water. Ind. Eng. Chem. Res., 46 (21), 6646-6649.

Rostron, W.M.; Stuckey, D.C.; Young, A.A., (2001). Nitrification of high strength ammonia wastewaters: comparative study of immobilisation media. Water Res., 35, 1169-1178.

Saupe, A., (1999). High-rate biodegradation of 3- and 4-nitroaniline. Chemosphere, 39 (13), 2325-2346.

Tashauoei, H.R.; Movahediam, H.; Amin, M.M.; Kamali, M.; Nikaeen, M.; Vahid, M., (2010). Removal of cadmium and humic acid from aqueous solutions using surface modified nanozeolite A. Int. J. Environ. Sci. Technol., 7 (3), 497-508.

Tilaki, R.A.D., (2011). A study on using fireclay as a biomass carrier in an activated sludge system. J. Ind. Microb. Biotechnol., 38 (1), 209-213.

Tortosa, G.; Correa, D.; Sánchez-Raya, A.J.; Delgado, A.; Sánchez-Monedero, M.A., Bedmar E.J., (2011). Effects of nitrate contamination and seasonal variation on the denitrification and greenhouse gas in La Rocina Stream (Doñana National Park SW Spain). Ecol. Eng., 37, 539-548.

Wang, Q.; Han, Zh.; Wang, T.; Zhang, R., (2008). Impacts of biogenic emissions of VOC and $\mathrm{NO}_{\mathrm{x}}$ on tropospheric ozone during summertime in eastern China. Sci. Total Environ., 395, 41-49.

Wu, W.; Cong, L.; Wang, J., (2009). The influence of aeration rate on partial nitrification in sequencing batch reactor. Int. J. Environ. Pollut., 38 (1-2), 193-202.

Yan, J.; Hu, Y.Y., (2009). Partial nitrification to nitrite for treating ammonium-rich organic wastewater by immobilized biomass system. Bioresour. Technol., 100, 2341-2347.

Yang, L., (1997). Investigation of nitrification by co-immobilized nitrifying bacteria and zeolite in a batchwise fluidized bed. Water Sci. Technol., 35 (8), 169-175.

Zaman, A.U., (2010). Comparative study of municipal solid waste treatment technologies using life cycle assessment method. Int. J. Environ. Sci. Technol., 7 (2), 225-234. 
445 Table 1: Composition and main features of Chilean natural zeolite (Clinoptilolite type) used in 446 the three sets of experiments carried out.*

\begin{tabular}{cc}
\hline Component & Composition (\%) \\
\hline $\mathrm{SiO}_{2}$ & 67.00 \\
$\mathrm{Al}_{2} \mathrm{O}_{3}$ & 13.01 \\
$\mathrm{Fe}_{2} \mathrm{O}_{3}$ & 3.60 \\
$\mathrm{CaO}$ & 3.46 \\
$\mathrm{Na}_{2} \mathrm{O}$ & 1.32 \\
$\mathrm{TiO}_{2}$ & 0.28 \\
$\mathrm{MgO}$ & 0.78 \\
$\mathrm{~K}_{2} \mathrm{O}$ & 0.53
\end{tabular}


Table 2: Composition of the synthetic wastewater used.

\begin{tabular}{ccc}
\hline & Units & Concentration \\
\hline $\mathrm{COD}$ & $\mathrm{mg} \mathrm{O} / \mathrm{L}$ & 360 \\
$\left(\mathrm{NH}_{4}\right)_{2} \mathrm{SO}_{4}$ & $\mathrm{mg} \mathrm{N} / \mathrm{L}$ & 707.1 \\
$\mathrm{MgSO}_{4} \cdot 7 \mathrm{H}_{2} \mathrm{O}$ & $\mathrm{mg} \mathrm{Mg} / \mathrm{L}$ & 3.6 \\
$\mathrm{~K}_{2} \mathrm{HPO}_{4}$ & $\mathrm{mg} \mathrm{P} / \mathrm{L}$ & 43.9 \\
$\mathrm{KH}_{2} \mathrm{PO}_{4}$ & $\mathrm{mg} \mathrm{P} / \mathrm{L}$ & 43.9 \\
\hline
\end{tabular}

474

475

476

477

478

479

480

481

482

483

484

485

486

487

488

489

490

491

492

493

494

495

496

497

498

499

500

501 
503 Table 3: Variation of the average biomass concentration and $\mathrm{pH}$ values (with their respective 504 standard deviations) with time in the set of experiments III.

\begin{tabular}{ccc}
\hline $\begin{array}{c}\text { Time } \\
(\text { days })\end{array}$ & $\begin{array}{c}\text { Average VSS concentration } \\
(\mathrm{ppm})\end{array}$ \\
\hline 0 & $1,000 \pm 40$ & $7.8 \pm 0.4$ \\
2 & $7,800 \pm 390$ & $7.1 \pm 0.4$ \\
4 & $6,700 \pm 340$ & $6.5 \pm 0.3$ \\
6 & $11,300 \pm 450$ & $6.5 \pm 0.1$ \\
8 & $11,550 \pm 530$ & $6.3 \pm 0.1$ \\
10 & $11,700 \pm 480$ & $6.2 \pm 0.2$ \\
12 & $13,900 \pm 520$ & $6.1 \pm 0.3$ \\
14 & $12,200 \pm 450$ & $6.3 \pm 0.4$ \\
16 & $12,100 \pm 490$ & $6.4 \pm 0.3$ \\
\hline
\end{tabular}

505

506

507

508

509

510

511

512

513

514

515

516

517

518

519

520

521

522

523

524

525

526 
528 Table 4: Variation of the average nitrogenous compounds $\left(\mathrm{NH}_{4}{ }^{+}\right.$and $\left.\mathrm{NO}_{3}{ }^{-}\right)$with their 529 respective standard deviations with time in the set of experiments III.

\begin{tabular}{ccc}
\hline $\begin{array}{c}\text { Time } \\
(\text { days })\end{array}$ & $\begin{array}{c}\mathrm{NH}_{4}{ }^{+} \\
\text {(molar concentration) }\end{array}$ & $\begin{array}{c}\mathrm{NO}_{3}{ }^{-} \\
\text {(molar concentration) }\end{array}$ \\
\hline 2 & $0.0020 \pm 0.0001$ & $0.0022 \pm 0.0001$ \\
4 & $0.0035 \pm 0.0001$ & $0.0040 \pm 0.0001$ \\
6 & $0.0037 \pm 0.0002$ & $0.0048 \pm 0.0002$ \\
8 & $0.0040 \pm 0.0002$ & $0.0059 \pm 0.0001$ \\
10 & $0.0042 \pm 0.0001$ & $0.0075 \pm 0.0002$ \\
12 & $0.0049 \pm 0.0002$ & $0.0200 \pm 0.0008$ \\
14 & $0.0050 \pm 0.0002$ & $0.0185 \pm 0.0007$ \\
16 & $0.0049 \pm 0.0002$ & $0.0189 \pm 0.0008$ \\
\hline
\end{tabular}

530

531

532

533

534

535

536

537

538

539 


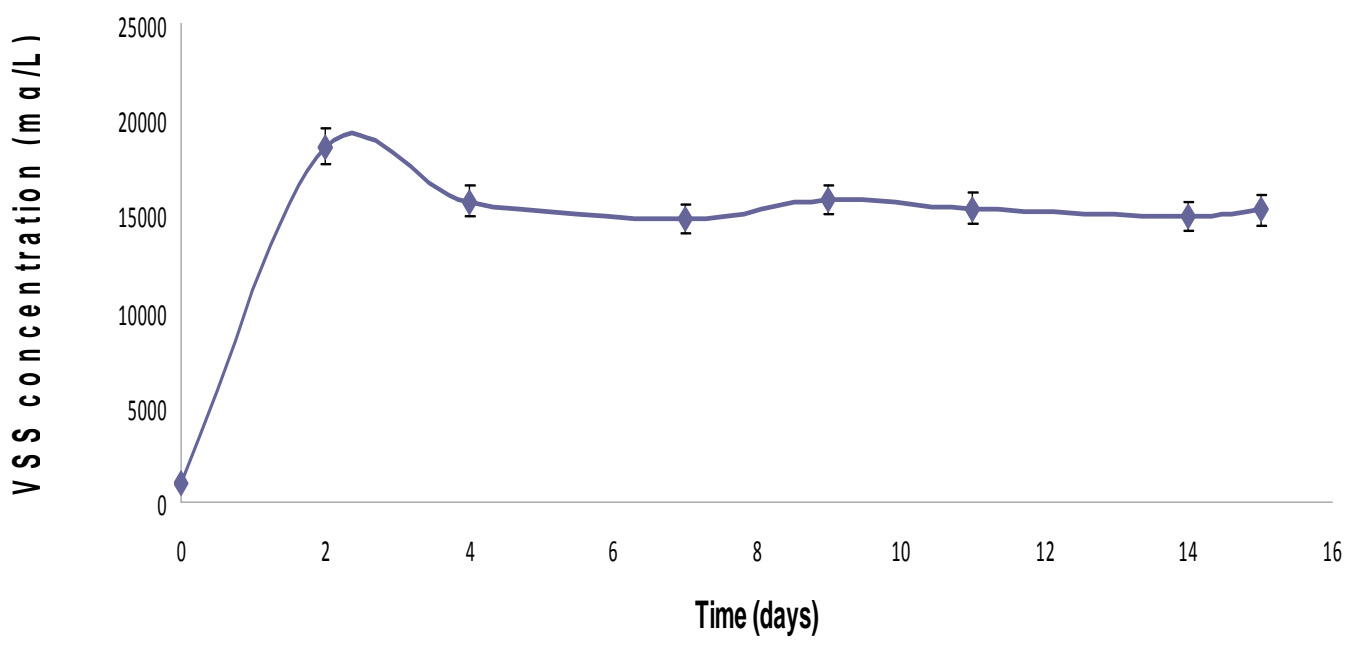

Figure 1: Variation of the biomass concentration $(\mathrm{mg} \mathrm{VSS} / \mathrm{L})$ with time in the reactors 543 with zeolite (initial biomass concentration of $1000 \mathrm{mg} \mathrm{VSS} / \mathrm{L}$ ) in the set of experiments I. 


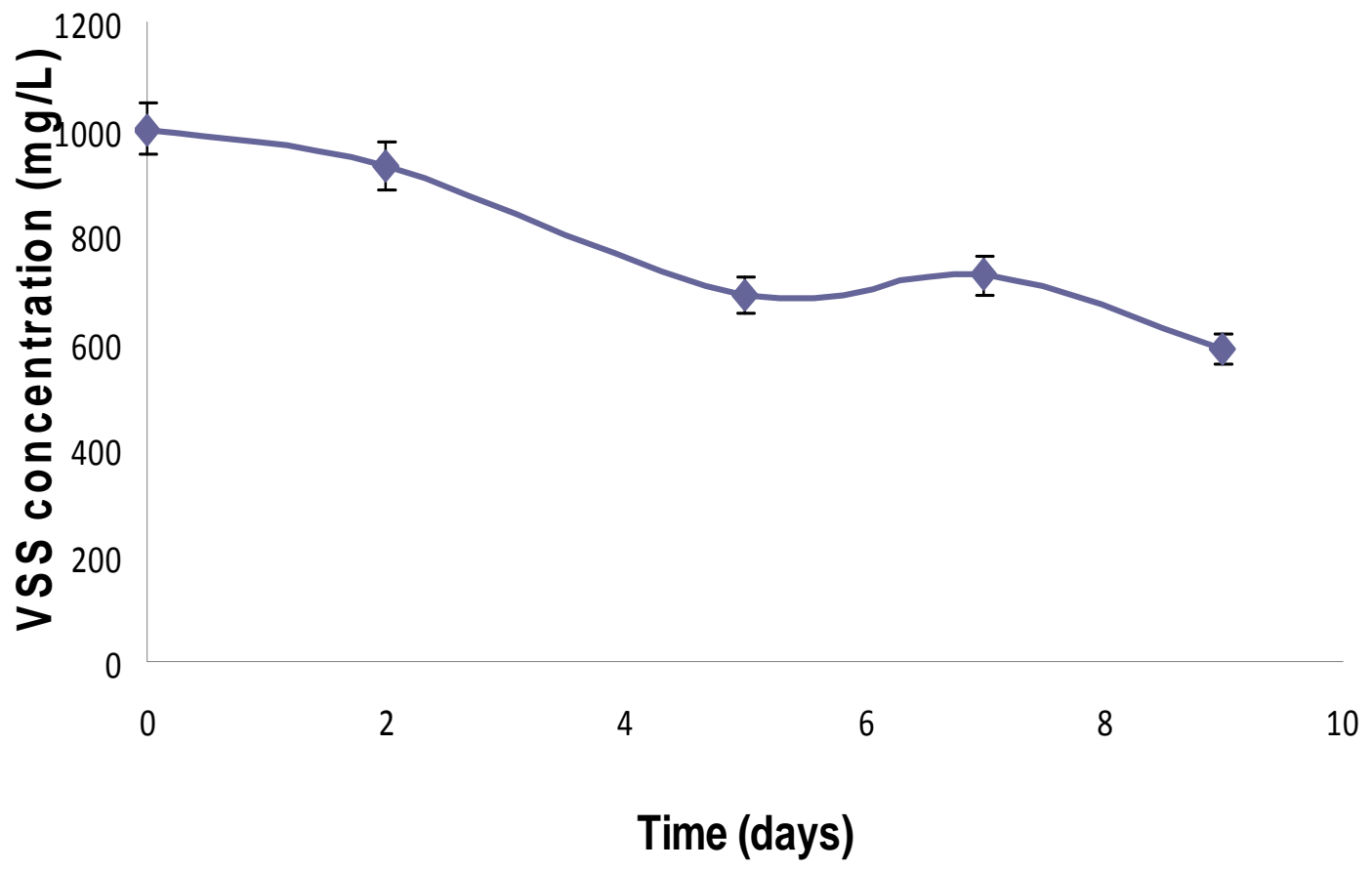

Figure 2: Variation of the biomass concentration $(\mathrm{mg} \mathrm{VSS} / \mathrm{L})$ with time in the reactors without zeolite (initial biomass concentration of $1000 \mathrm{mg} \mathrm{VSS} / \mathrm{L}$ ) in the set of experiments I. 


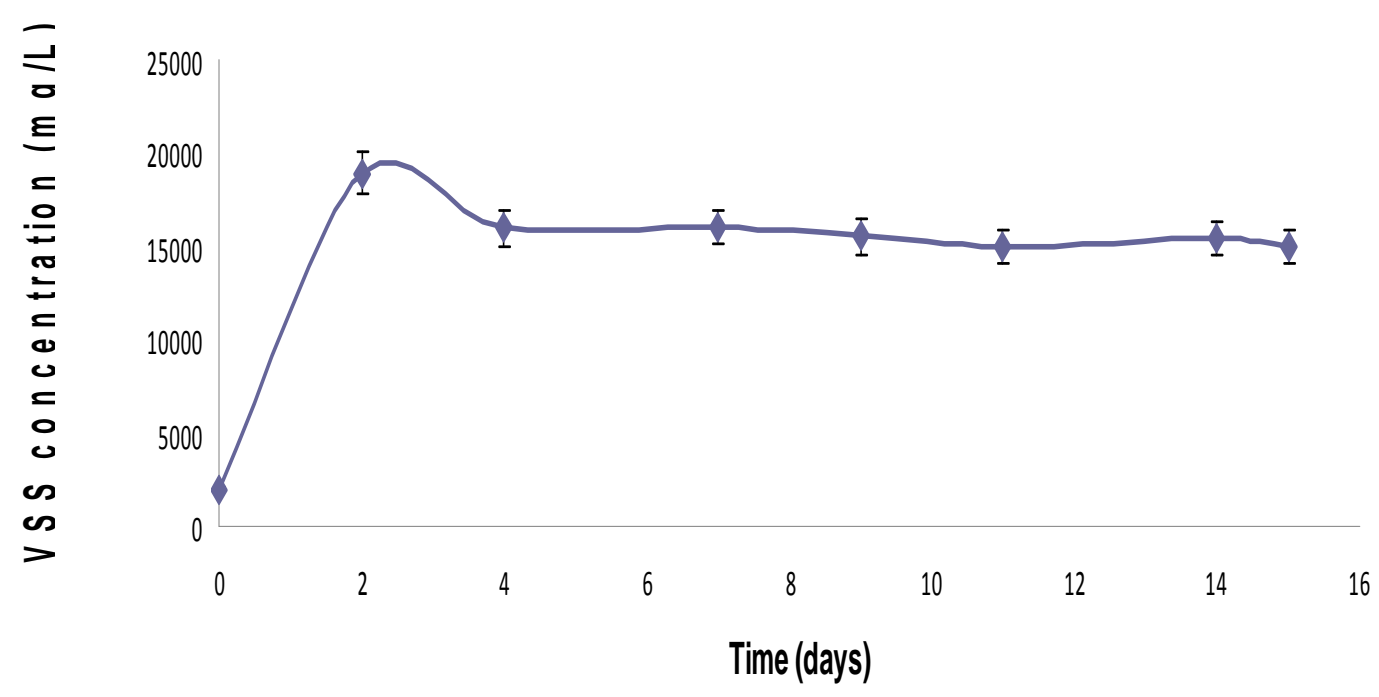

604

Figure 3: Variation of the biomass concentration $(\mathrm{mg} \mathrm{VSS} / \mathrm{L})$ with time in the reactors 606

607 with zeolite (initial biomass concentration of $2000 \mathrm{mg} \mathrm{VSS} / \mathrm{L}$ ) in the set of experiments I.

608

609

610

611

612

613

614

615

616

617

618

619

620

621

622

623

624

625

626

627

628

629

630

631

632

633

634

635

636

637 


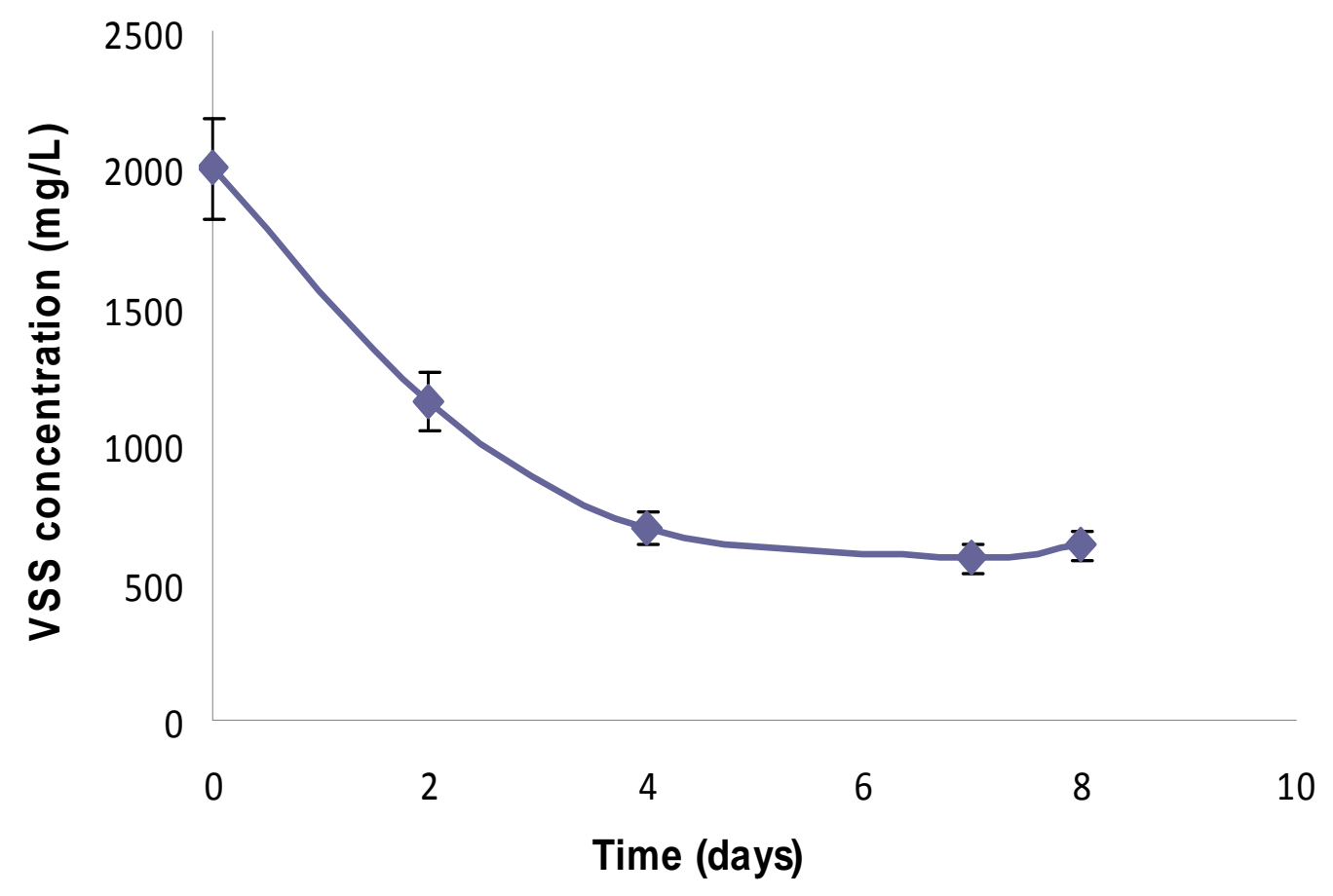

638

Figure 4: Variation of the biomass concentration (mg VSS/L) with time in the reactors without zeolite (initial biomass concentration of $2000 \mathrm{mg} \mathrm{VSS} / \mathrm{L}$ ) in the set 641 of experiments I.

642

643

644

645

646

647

648

649

650

651

652

653

654

655

656

657

658

659

660

661

662

663

664

665

666

667 


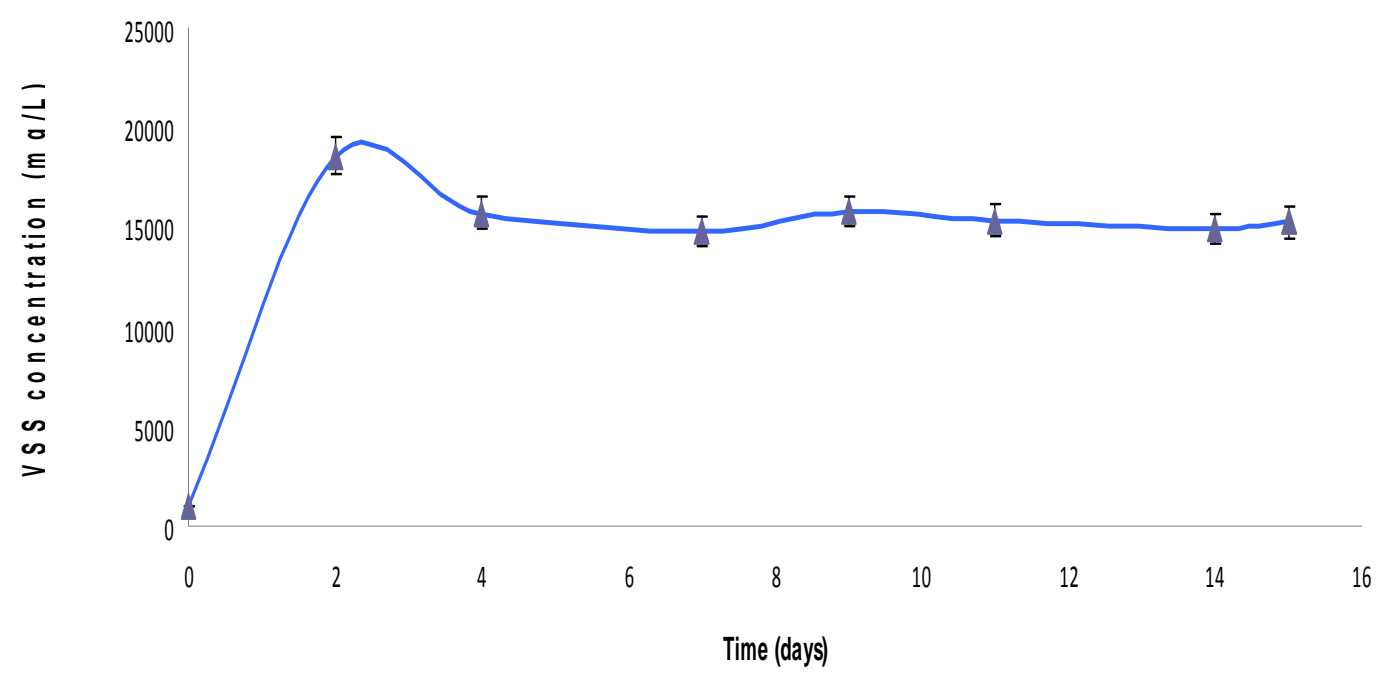

668

669

670 Figure 5: Variation of the biomass concentration with time in the set of experiments II 671 (initial biomass concentration: $1000 \mathrm{mg} \mathrm{VSS} / \mathrm{L}$ ).

672

673

674

675

676

677

678

679

680

681

682

683

684

685

686

687

688

689

690

691

692

693

694

695

696

697

698 


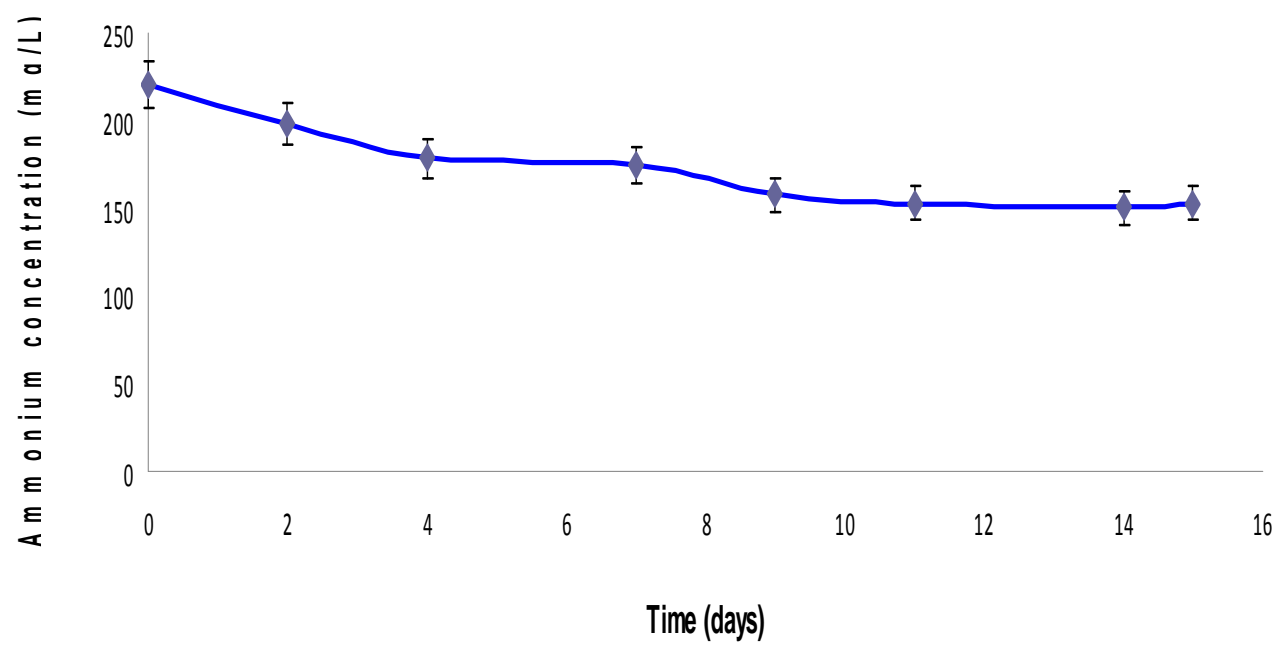

Figure 6: Variation of the ammonium concentration with time in the set of experiments II (initial biomass concentration: $1000 \mathrm{mg} \mathrm{VSS} / \mathrm{L}$ ).

703

704

705

706

707

708

709

710

711

712

713

714

715

716

717

718

719

720

721

722

723

724

725

726

727 


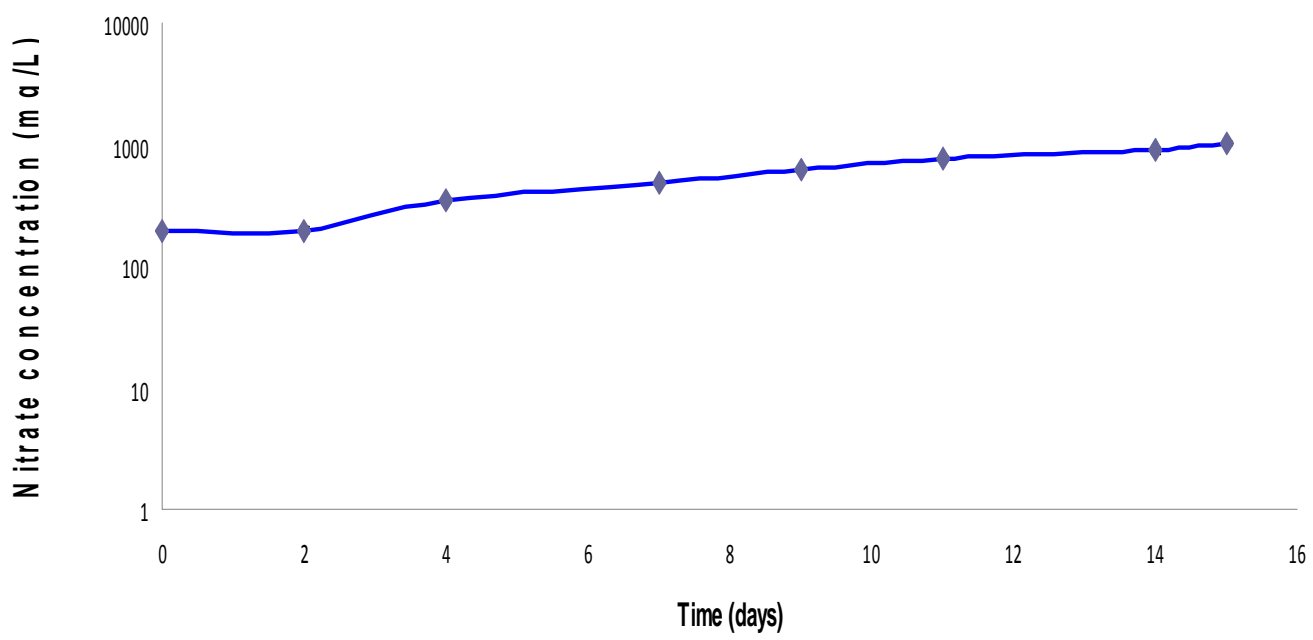

737

738

739

740

741

742

743

744

745

746

747

748

749

750

751

752

753

754

755

756

757

758

Figure 7: Variation of the nitrate concentration with time in the set of experiments II (initial biomass concentration: $1000 \mathrm{mg} \mathrm{VSS} / \mathrm{L}$ ). 


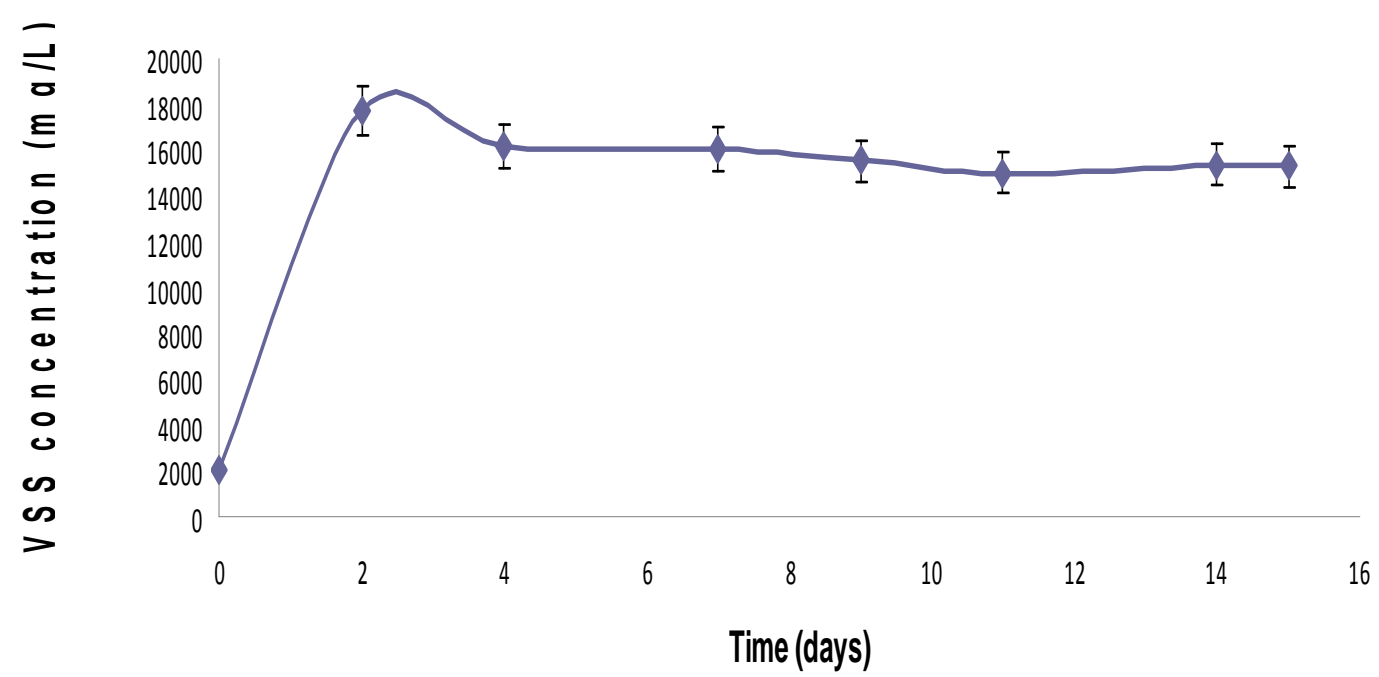

Figure 8: Variation of the biomass concentration with time in the set of experiments II (initial biomass concentration: $2000 \mathrm{mg} \mathrm{VSS} / \mathrm{L}$ ). 


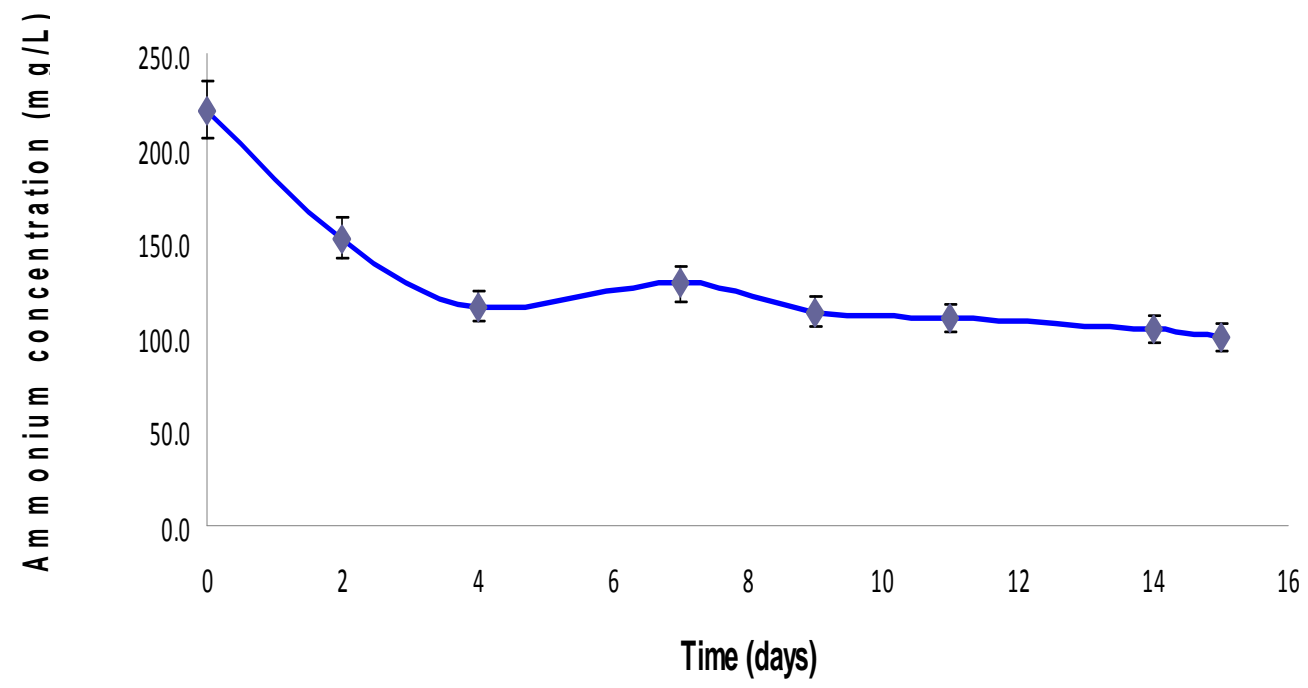

Figure 9: Variation of the ammonium concentration with time in the set of experiments II (initial biomass concentration: $2000 \mathrm{mg} \mathrm{VSS} / \mathrm{L}$ ).

792

793

794

795

796

797

798

799

800

801

802

803

804

805

806

807

808

809

810 


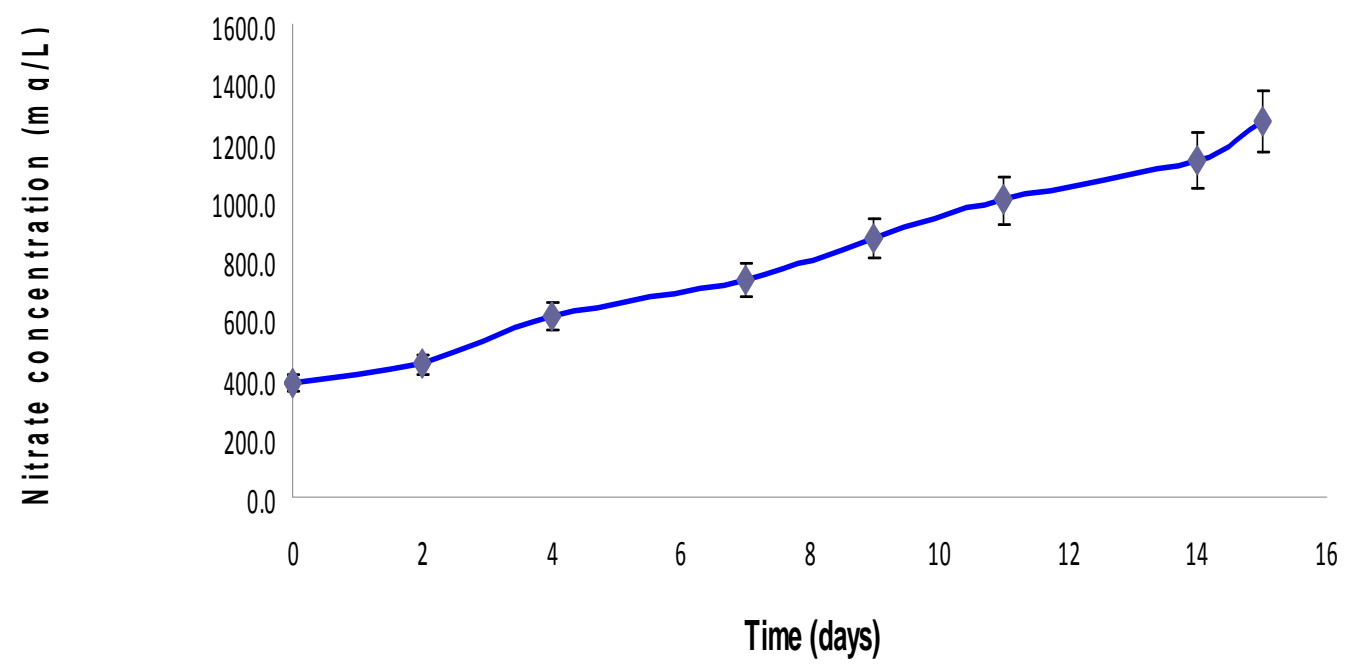

811

812

813 Figure 10: Variation of the nitrate concentration with time in the set of experiments II 814 (initial biomass concentration: $2000 \mathrm{mg} \mathrm{VSS} / \mathrm{L}$ ).

815

816

817

818

819

820

821

822

823

824

825

826

827

828

829

830

831

832

833

834

835

836

837

838

839 